\title{
動的な液体架橋による粒子間付着メカニズムの解明 \\ Elucidation of Mechanism of Particle-Particle Adhesion by Dynamic Liquid Bridge
}

\author{
援助対象者 Scholarship Student: 菅 裕之 Hiroyuki KAN \\ 大阪府立大学大学院工学研究科 博士課程後期 1 年 \\ Graduate School of Engineering, Osaka Prefecture University, PhD Student (D1) \\ E-mail: hkan@chemeng.osakafu-u.ac.jp
}

\begin{abstract}
研究指導者 Academic Leader：仲村 英也 Hideya NAKAMURA
\end{abstract}
准教授, Associate Professor

E-mail: hnakamura@chemeng.osakafu-u.ac.jp

\section{成 果 の 概 要}

目的

粉体を擋拌や流動化させながら結合液を添加 して，粒子同士を液架橋により凝集させる造粒 操作は, 様々な分野で用いられている重要な粉 体プロセスである。造粒物の物性は，これを元 に製造される製品の品質や機能を大きく左右す る。そのため，造粒においてどのように原料粒 子が凝集体を形成するのかを理解することは重 要な課題である。特に，凝集体形成時の最も基 礎的な素過程である「液滴を介して粒子が衝突 する際の粒子付着現象」の解明が重要である. この粒子付着現象は, 液架橋の変形を伴いなが ら粒子同士が衝突・付着する非常に複雑な現象 であるため，実験による詳細な解析は困難であ る。そこで，数值シミュレーションによるアプ ローチが有効であると考え，これまでにシミュ レーションモデルを構築した ${ }^{[1]}$. 本研究では, 構築したシミュレーションモデルを用いて, 液 滴を介して粒子が衝突する際の粒子付着現象
に，固体粒子表面の濡れ性（接触角）が及ぼす 影響を解析した。

\section{数值シミュレーション手法}

粒子間に形成される液架橋の挙動を計算する ためには，固体・液体・気体を含む 3 相流れを 解く必要がある。本研究では, 数值流体力学 （CFD）を用いて気液 2 相流れを解き, 液架橋 から受ける力を外力として考慮した粒子に関す る運動方程式を解くことにより粒子運動挙動を 求めた。気液 2 相流れにおける基礎方程式とし て, 以下に示す連続の式, Navier-Stokes 式, 液 相カラー関数の移流方程式を用いた：

$$
\nabla \cdot \boldsymbol{u}=0
$$

$$
\frac{\partial \boldsymbol{u}}{\partial t}+(\boldsymbol{u} \cdot \nabla) \boldsymbol{u}=-\frac{1}{\rho_{\mathrm{f}}} \nabla p+\frac{\mu_{\mathrm{f}}}{\rho_{\mathrm{f}}} \nabla^{2} \boldsymbol{u}+\boldsymbol{f}_{\mathrm{sf}}+\boldsymbol{f}_{\mathrm{p}}+\boldsymbol{g}
$$

$$
\frac{\partial \phi}{\partial t}+(\boldsymbol{u} \cdot \nabla) \phi=0
$$


ここで, $\boldsymbol{u}, t, \rho_{\mathrm{f}}, p, \mu_{\mathrm{f}}, \boldsymbol{f}_{\mathrm{sf}}, \boldsymbol{f}_{\mathrm{p}}, \boldsymbol{g}$ は流体速度, 時間, 流体密度, 圧力, 流体粘度, 表面張力, 粒子一流体間相互作用力および重力加速度をそ れぞれ表す。また, 液相カラー関数 $\phi$ は流体相 の種類を区別するための変数であり, $\phi=0$ で は気相， $\phi=1$ では液相が計算格子を占めてい ることを示す。気液界面の変形挙動は Eq. (3) を 解くことにより求められる. Eq. (3) の数值計算 手法として Constrained Interpolation Profile (CIP) 法 ${ }^{[2]}$ を用いた。表面張力 $\boldsymbol{f}_{\text {sf }}$ は Continuous Surface Force（CSF） モデル ${ }^{[3]}$, 粒子 - 流体間相互作 用力 $\boldsymbol{f}_{\mathrm{p}}$ は埋め达み境界法 ${ }^{[4]}$ を用いて算出した。 次に, 粒子の運動挙動は以下の運動方程式を数 值積分することにより求めた：

$$
M_{\mathrm{p}} \frac{\mathrm{d} \boldsymbol{u}_{\mathrm{p}}}{\mathrm{d} t}=\boldsymbol{F}_{\mathrm{d}}+\boldsymbol{F}_{\mathrm{sf}}+\boldsymbol{F}_{\mathrm{cp}}+M_{\mathrm{p}} \boldsymbol{g}
$$

ここで, $M_{\mathrm{p}}, \boldsymbol{u}_{\mathrm{p}}, \boldsymbol{F}_{\mathrm{d}}, \quad \boldsymbol{F}_{\mathrm{sf}}, \boldsymbol{F}_{\mathrm{cp}}$ は粒子質量, 粒子速度, 流体抗力, 表面張力および毛管圧力 をそれぞれ示す．流体抗力 $\boldsymbol{F}_{\mathrm{d}}$ は粒子 - 流体間 相互作用力 $\boldsymbol{f}_{\mathrm{p}}$ を粒子体積で積分することによ り求め, 表面張力 $\boldsymbol{F}_{\text {sf }}$ は Continuous Capillary Force $(\mathrm{CCF})$ モデル [5] を用いて算出した。また, 毛管圧力 $\boldsymbol{F}_{\mathrm{cp}}$ は固液気 3 相境界で囲まれた面積 および液相と気相の圧力差から求めた。

\section{結果および考察}

流動層造粒に打ける粒子凝集過程を単純化し た系として, 粒子表面上に付着した液滴を介し て 2 粒子が衝突・付着する現象を解析した。 Fig. $1(t=0 \mu \mathrm{s})$ に示すように, 液滴が付着し た 2 粒子を法線方向に衝突させた。粒子物性に は $50 \mu \mathrm{m}$ のラクトース, 液体物性には水を用 いた. 本検討では, 粒子の相対衝突速度 $v\left(=\mid v_{1, \text { init }}\right.$ $\left.-v_{2, \text { nit }} \mid\right)$ を変化させ, 接触角 $\theta$ が粒子付着現象 に及ぼす影響を解析した。

Fig. 1 に， $\theta=30,120 \operatorname{deg}$ に扔ける $v=1.0 \mathrm{~m} / \mathrm{s}$ のシミュレーション結果を示す. $\theta=30 \mathrm{deg}$ の 場合 (Fig. 1 (a)), 粒子同士の衝突. 反発後, 液架橋は破断することなく最終的に 2 粒子は付 着した. 一方, $\theta=120 \operatorname{deg}$ の場合（Fig. 1 (b)),
粒子同士が衝突する前に反発し, 液架橋が粒子 表面から離れて 2 粒子は最終的に分離した。こ のように, 同じ相対衝突速度であっても, 接触 角によって粒子および液架橋の運動挙動は大き く異なることが分かった.

Fig. 2 に, 粒子付着・分離の境界速度である 臨界衝突速度 $v_{\mathrm{c}}$ と接触角の関係を示す。接触 角の増加に伴って臨界衝突速度も増加するが, $\theta=60 \mathrm{deg}$ で極大值を示し, それ以降では減少 した。このように, 臨界衝突速度はある接触角 において極值を持つことが分かった。これにつ いて詳細に解析したところ， $\theta=60 \mathrm{deg}$ は粒子 間液架橋がより大きく伸長することができ, か
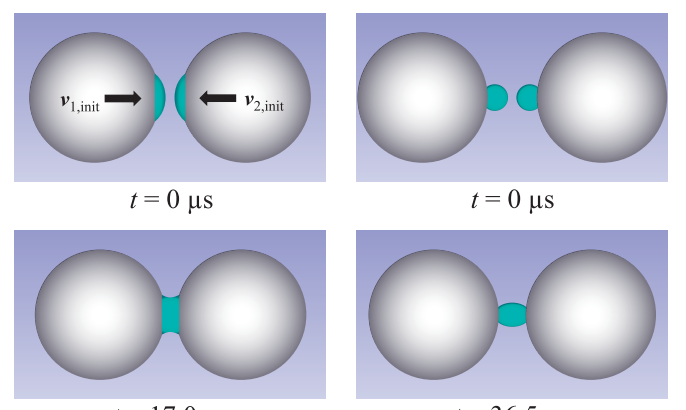

$t=17.0 \mu \mathrm{s}$

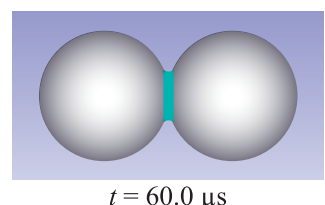

(a) $\theta=30 \mathrm{deg}$

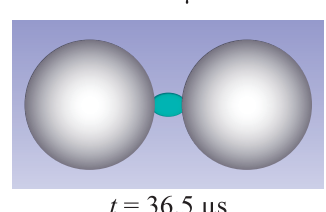

$t=36.5 \mu \mathrm{s}$

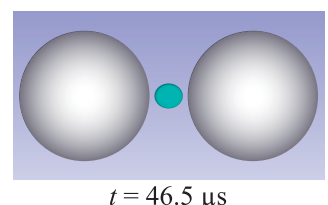

(b) $\theta=120 \mathrm{deg}$
Fig. 1 Behaviors of particles and liquid bridge at different contact angles $(v=1.0 \mathrm{~m} / \mathrm{s})$.

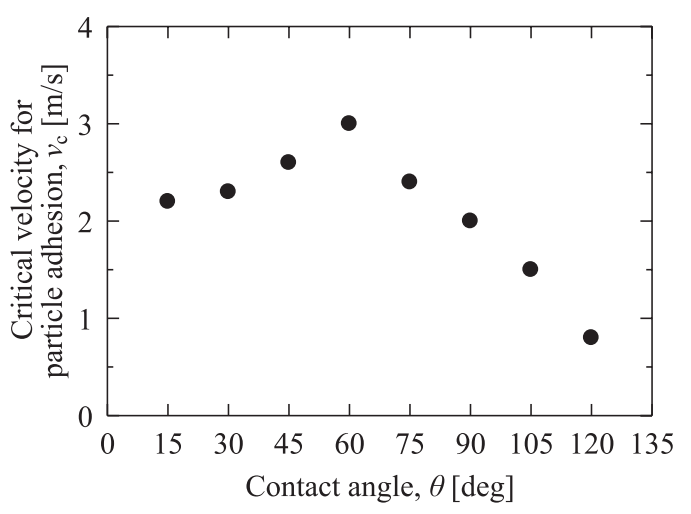

Fig. 2 Critical velocity for particle adhesion as a function of contact angle. 
つ粒子運動を減衰させるエネルギーが最大とな る条件であった。

\section{まとめ}

数值シミュレーションを用いて, 液滴を介し て粒子が衝突する際の粒子付着現象における, 濡れ性が及ぼす影響を検討した。その結果，臨 界衝突速度はある接触角において極值を持ち, 臨界衝突速度には液架橋の伸長距離が大きく寄

\section{外部発表成果}

\section{論文発表}

1. Kan H., Nakamura H. and Watano S, Numerical simulation of particle-particle adhesion by dynamic liquid bridge, Chem. Eng. Sci. 138 (2015), 607-615.

\section{口頭・ポスター発表}

1. 菅裕之, 仲村英也, 綿野哲, “湿式造粒プ ロセスにおける粒子間付着現象の数值解
与することを明らかにした

\section{参考文献}

[1] H. Kan et al., Chem. Eng. Sci., 138, 607-615 (2015)

[2] T. Yabe et al., J. Comput. Phys., 169, 556-593 (2001)

[3] J. U. Brackbill et al., J. Comput. Phys., 100, 335-354 (1992)

[4] T. Kajishima et al., Int. J. Heat Fluid Flow, 23, 639649 (2002)

[5] K. Washino et al., Chem. Eng. Sci., 93, 197-205 (2013)

析”, 粉体工学会第 50 回技術討論会「造粒 と成形」(大阪，2015 年 6 月) .

2. 菅裕之, 仲村 英也, 綿野哲, “液滴を介し て粒子が衝突する際の粒子付着現象の数值 解析”, 2015 年度第 2 回粉体操作に伴う諸 現象に関する勉強会（滋賀, 2015 年 8 月).

3. 菅裕之, 仲村英也, 綿野哲, “液滴を介し て粒子が衝突する際の粒子付着現象の解 析”, 第 32 回製剤と粒子設計シンポジウム, 愛知 (2015 年 10 月).

4. 菅裕之, 仲村 英也, 綿野哲, “固体表面の 濡れ性が粒子付着現象に及ぼす影響”, 化学 工学会第 81 年会, 大阪 (2016 年 3 月). 